\title{
The Reform of Innovative Talent Training Mode Based on University-Enterprise and Industry-University-Research Platform
}

\author{
Wang Hailing \\ (Xiamen University Tan Kah Kee Colledge, College of Information Science and Technology,Xiamen, \\ 363105,Fujian)
}

Key words: School-enterprise cooperation, Production, Innovative talents, Reform

\begin{abstract}
Undergraduate education implements many years of the teaching model about the practice of the first theory after the practice, students often lack the necessary perceptual knowledge, and it is difficult to adapt to the rapid "accumulation" of theoretical knowledge, and be unable to form intrinsic learning motivation. Therefore, in order to change the traditional teaching mode based on classroom knowledge and adapt to the transformation of economy and society and the change of human needs, it urgently calls for the reform of innovative talent training mode. Based on the combination of industry-university-research competition, this paper realizes the integration of teaching, scientific research, production and competition: To acquire new knowledge in scientific research, to impart new knowledge in teaching, to apply new knowledge in production, and to practice knowledge in competitions.
\end{abstract}

\section{Introduction}

In recent years, with the continuous deepening of Internet + and artificial intelligence, disciplinary intersections have been gradually enhanced, and the transformation of economic society and the change of human needs call for the reform of talent training mode. How to cultivate talents, academic talents who can be in an "ivory tower" in the past ,but now applied and innovative talents who must be not only in an "ivory tower", and have to "production", "learning", " research " and "race". Through the establishment of an innovation platform, we can inspire and guide teachers, students and enterprises to participate in the "four-wheel drive" cooperation model of production, learning, research and competition. Through cooperation platform, the school guides students to participate in relevant competitions and improves students' innovative ability. Through investment, enterprises can transform the innovative ideas of students into achievements and maximize the role of talent cultivation. Practice has proved that improving education level, cultivating high quality application-oriented and innovative talents must follow the combination of industry-university-research competition.

\section{Reform the teaching method and realize the new knowledge in the scientific research.}

In the traditional teaching mode, teachers are busy with the heavy teaching tasks such as preparing lessons, taking classes, changing homework and counseling. Teachers have no time to think about scientific research problems or subjects that are not of interest to them. Through school-enterprise cooperation, it can be found that some non-theoretical problems need to be solved in practice. The combination of industry-university-research and research will help to clearly understand the new trend of current technology development, realize the breakthrough of enterprises in technology, and shorten the time of the transformation of scientific and technological achievements into actual production capacity.

\section{Reform the teaching idea and realize teaching new knowledge in the teaching.}

At present, most of the undergraduate education is still based on knowledge indoctrination, which seriously kills the students' initiative and creativity, thus leading to students' ignorance of their own reasons. The specific performance is as follows: 
(1) Because the traditional teaching model, students learn the main course for specialized courses and common course required parts of the country by the ministry of education, liberal arts of cross and fusion is less, the discipline knowledge is superficial.

(2) The first to obtain the theoretical knowledge, which makes lots of students to innovative consciousness are vague, and believe that science and technology innovation activity that are far away from them, and they don't believe they have the ability to participate in scientific and technological innovation. Moreover, the participating in project research and development's enthusiasm is not high.

(3) Many students don't have a correct understanding of scientific research innovation practice activity and the relationship between work and other study, they feel that the papers need to spend too much time, and their learning task is very heavy, which lead to many students don't know for scientific research and innovation.

Based on this, we should make full use of school and enterprise, scientific research units, subject contests, a variety of different education environment and education resources, their respective advantages in talents cultivation, we can compact the classroom knowledge of school education with the direct access to the practical experience, and give priority to the practice ability which is given priority to the production, scientific research and practice of organic combination of the forms of education. From multi-level, all-round, three-dimensional framework university enterprise cooperation, teachers and students participate in mode. The teachers become the teaching of organizers, instructors, counselors from the imparter of knowledge, the students becomes the knowledge of active builders from the receiver. Details are as follows:

(1) Hold regular lectures and technical exchanges. Give lectures and broaden your horizons; Carry out technical exchanges, share their own opinions, and realize the collision of thinking.

(2) Platform class. Students are free to choose courses according to their own interests, not subject to the restrictions of the arts and sciences, and give credit to them.

(3) Encourage students to participate in research and development projects and implement incentive systems. Adopt the distribution according to work, many labor, work integral examination and verification system, according to the integral high and low pay the labor expense subsidy. At the same time to those in the study, research shows that some students can obtain certain result issued certificates of honor, bonuses, etc., can even an exemption to recommend one of the excellent students to graduate school.

\section{Reform the new model of school-enterprise cooperation and realize the application of new knowledge in production.}

Traditional school-enterprise cooperation only stays in the enterprise donation equipment or form of co-construction. There is only a focus on the current benefit, and it is not willing to spend the extra money on developing new products and improving the competitiveness of existing products. In fact, any enterprise no matter how big scale, technical ability how diversification, it is impossible to have technical ability needed for every field, it will become the biggest bottleneck restricting enterprises engaged in technological innovation. Therefore, it is necessary to further deepen school-enterprise cooperation, standardize school-enterprise cooperation mode, realize cooperation mechanism, system, personnel training and other innovations, and specific measures are as follows:

(1) We will improve the construction of school-enterprise platforms, exchange regular exchanges between schools and enterprises, organize cooperation salons, and carry out school-enterprise cooperation and linkage mechanism. One is that the teachers who participate in the platform construction can come from different departments, so it can realize the sharing of knowledge within the school. The second is to point out the problems existing in the reality, and the teachers can correct the research direction according to the bottleneck of the technological innovation of enterprises. Enterprises can solve theoretical problems through college teachers, so as to realize the mechanism innovation of win-win cooperation.

(2) Establish inspection and feedback mechanism for school-enterprise cooperation process. Enhancing university-enterprise cooperation process management, pay attention to the 
accumulation of process data, promote the schools at all levels of university-enterprise cooperation activities consciously, long-term and institutionalize

$-\mathrm{d}$, so as to realize the mechanism innovation of "four one"

(3) Introduce the factory into the teaching, and jointly declare the subject, patent and so on. On the one hand, the teachers of the school choose the relatively stable enterprises to carry out the practice according to the research direction, increase the training of teachers and students, and participate in the development and design of new products. On the other hand, invite enterprise engineers, managers at all levels of school as a part-time teachers guide students to practice, participate in project research and development, intensify students' innovative entrepreneurial training.

\section{Reform the credit identification method and realize the knowledge in the discipline competition.}

Through the science and technology competition and scientific research innovation project, strengthen students' professional skill level and cultivate the students' team spirit. Organizing students to participate in all kinds of science and technology competitions in this major is not only a test of the talent training mode of "industry-university-research", but also a platform for students to demonstrate their hands-on ability and professional skills.

To this end, the school has issued the "students innovation and entrepreneurship practice activity credit identification method", Competition, research of the discipline, the college students' innovative entrepreneurial training programs, academic works, such as patent for credits that improve the enthusiasm of students to participate in activities in the competition and achieve the sublimation of learning knowledge innovation entrepreneurship competition.

\section{Summary}

The whole academic atmosphere of our school has been thoroughly promoted through the construction of four parts. Meanwhile, academic participation in extracurricular innovation, entrepreneurship, research and competition is highly motivated. And students had won the national and provincial special prizes, first prize and second prize several times in the TI cup Internet of things design competition, National college student smart car competition, National (fujian) college students electronic design competition, National (fujian) university students mathematical modeling contest and so on.

\section{Acknowledgement}

This paper was supposed by the Fujian education reform project(FBJG20170154) and School grade reform project and the field incubation project 2015L02 and Zhangzhou natural science fund(ZZ2018J26).

\section{Reference}

[1] Kong Bin, Li Xuebin, Pan Xingang. An empirical analysis of the cooperation model of local colleges and universities in ethnic areas. [J]. Scientific and technological progress and countermeasures, 2010,27(24):68-70.

[2]Zhang Liang. Research and practice on the construction of practical teaching innovation platform based on school-enterprise cooperation. [J]. Journal of hunan institute of engineering (social science edition),2013,23(3):84-86.

[3] Huang Wen,Li Wen. Research on the cultivation mode of "industry-university-research innovation" for computer science undergraduates. [J]. computer education,2017,8:43-46. 
[4] Dong Xin,Wu Wei,Wang Yiheng. Research on school-enterprise cooperation model based on collaborative innovation concept. $[\mathrm{J}]$. Journal of national education administration institute.,2014,7:59-63.

[5] Wei Zhiling. Construction and research of virtual industrial robot experimental training room. [J]. Techniques of Automation and Applications,2013,32(8):85-88. 